\title{
Hamsa
}

H俞MSA Journal of Judaic and Islamic Studies

$6 \mid 2020$

Varia

\section{A Moor of Granada: Prophecies as political instruments in the entangled histories of Spain, Portugal, and the Middle East 16th-18th centuries}

Mònica Colominas Aparicio and Gerard Wiegers

\section{(2) OpenEdition}

1 Journals

\section{Electronic version}

URL: https://journals.openedition.org/hamsa/277

DOI: $10.4000 /$ hamsa.277

ISSN: 2183-2633

Publisher

CIDEHUS - Centro Interdisciplinar de História Culturas e Sociedades da Universidade de Évora

\section{Electronic reference}

Mònica Colominas Aparicio and Gerard Wiegers, "A Moor of Granada: Prophecies as political instruments in the entangled histories of Spain, Portugal, and the Middle East 16th-18th centuries", Hamsa [Online], 6 | 2020, Online since 30 April 2020, connection on 13 May 2021. URL: http:// journals.openedition.org/hamsa/277 ; DOl: https://doi.org/10.4000/hamsa.277

This text was automatically generated on 13 May 2021.

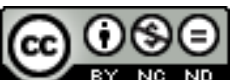

Hamsa est mise à disposition selon les termes de la Licence Creative Commons Attribution - Pas d'Utilisation Commerciale - Pas de Modification 4.0 International. 


\title{
A Moor of Granada: Prophecies as political instruments in the entangled histories of Spain, Portugal, and the Middle East 16 th-18th centuries
}

\author{
Mònica Colominas Aparicio and Gerard Wiegers
}

\section{Introduction}

1 The use of prophecy as a political instrument within medieval and early modern Mediterranean societies is often connected to the widespread idea of the arrival of a messianic king who will rule during the end times and who will be anticipated by the Antichrist. In the Iberian context of the prophetic text, on which we will focus, two traditions may be distinguished. First, there is the prophetic tradition discussed by Alain Milhou. Here, prophecy serves as a tool in the political and armed struggle between rival groups. Milou argues that the main structure of messianic prophecies in Spain is derived from the destruction-renovation scheme, which became associated with Isidore of Seville (ca. 560-636) in the early $15^{\text {th }}$ century ${ }^{1}$. 'Destruction' here refers to the última monarquía (last monarchy). Isidore predicted that the Visigoth Kingdom would fall at the hands of the Muslims. The final monarchy would be ruled by Christian kings who would be ultimately be victorious in their struggle against the Muslim invaders, and would restore unity to Hispania. Milhou marks out cycles of hope and defeat in which he identifies a correlation between mounting tensions and the increasing publication of prophetic texts. Prophecies served the religious-political goal by strengthening the morale of the readers, which further served as an ideological tool in the armed struggle. In Spain, Milhou argued, the intensity increased in an almost cyclical way and in connection to particular moments in the political relations between the religious and ethnic communities. An example of this can be seen in the fall of 
Constantinople when prophecies of its fall and the eschatological implications circulated among Muslims, Jews and Christians in Spain ${ }^{2}$. Messianic expectations also increased during the conquest of Granada, especially during the last year (1491), when the Catholic kings were preparing the final siege ${ }^{3}$. Another example can be seen during the Revolt of the Moriscos in the Alpujarras in 1568-1570 and their subsequent expulsion from Spain by King Phillip III between 1609 and 1614, in an attempt to quell Islamic heresy in Spain once and for all ${ }^{4}$.

2 In Portugal, prophecy had a different trajectory than the destruction-renovation scheme, one based primarily on the Joachimite prophetic tradition, which claimed that the Portuguese nation would be delivered from evil by a sacred king. As Portugal was ruled by the Spanish Crown, this prophetic tradition had a particularly strong antiSpanish flavor. The first known connection to Islam appeared in the early sixteenth century work of Gonçalo Anes Bandarra, a former shoemaker (sapateiro) in Trancoso. In his widely disseminated Trovas, Bandarra foresaw the coming of a Portuguese king who would convert the Jews, destroy the "Turks" (i.e. the Muslims), and bring universal peace ${ }^{5}$. When King Sebastian (1554-1578) disappeared during the Battle of Three Kings in Alcazarquivir (Morocco) in 1578, rumor had it that he had not in fact been killed by his Muslim opponents, but rather had escaped, and was living undercover. The messianic expectation of this story, in its simplest form, is the belief that Sebastian would one day return, and restore divine right to Portugal. This divine right was associated with the Ourique myth-the mythical divine intervention favoring the Portuguese during the battle of Ourique in 1139 against the Almoravids-and originated in the late fifteenth century. Lucette Valensi points out that the notion that Sebastian survived the battle was legitimized by alleged Muslim prophecies about his return ${ }^{6}$. The belief in Sebastian's return was so strong that already at the beginning of the seventeenth century, in 1603, Dom João de Castro cited Bandarra's poems, convinced that the living Sebastian (supposedly seen in Venice) was the Hidden One, i.e. the invisible expected saviour. Castro himself wrote Da quinta e ultima Monarquia futura (The fifth and last future monarchy) in 1597, in which he predicted that Sebastian would overthrow Islam and reform the Church with the help of the Angelic Pope ${ }^{7}$. The influence of pseudo-Isidore and Ourique myths can be seen in this text, as can a close connection between Sebastianism and Islam.

3 In this paper, we will focus on a source that has not been analyzed in modern scholarship so far-a brief prophetical text entitled "Profesias dadas por um Mouro de Granada" [henceforth, "Moor of Granada"]. The text is found in the Curious and interesting miscellaneous manuscript, copied (and perhaps authored) by two or more different and anonymous persons in eighteenth century Portugal ${ }^{9}$. The manuscript claims that the prophetical text had originally been written in Arabic and was then translated into Portuguese (the language in which our manuscript is written), in 1510. (We have included a transcription of the text in the appendix.)

4 In the first section we will study the sources used in the miscellaneous manuscript, which includes our text. Then, we will analyze the prophecy of the "Moor of Granada" and its background. Finally, in the third section we will discuss its Sebastianist background in consideration of European millenarian beliefs in general, and Portuguese messianic beliefs in particular. 


\section{The Contents of the "Curious and Interesting" Miscellaneous manuscript}

$5 \quad$ First it must be noted that the title of the manuscript miscelaneas curiozas e interesantes em manuscrito uses the plural, a detail that emphasizes the nature of what appears to be a motley compilation of different texts. The manuscript itself dates from the eighteenth century, however a good number of the Portuguese and Spanish texts were written much earlier. They can indeed be called "curious." One "curiosity," for example, is a description of twenty-four panels that the city of Évora is said to have presented to the Portuguese King João $\mathrm{IV}^{10}$ as a compensation for a royal favor. The document mentions the names of the famous personalities represented in each of the panels, as well as the texts engraved on the "very well polished and decorated" moldings ${ }^{11}$. João's accession to the throne in 1640 led to a war with Spain, and ultimately to the restoration of independence to Portugal from the Spanish empire. It is, therefore, not surprising that the first panel is dedicated to King João. He is depicted surrounded by prostitutes and soldiers, while the second panel represents his main political opponent, the Spanish king's minister Don Gaspar de Guzmán, Count-Duke of Olivares. At the foot of the panel depicting the Count-Duke stands, "whoever has already seen this painting, has seenfrom Spain-the Antichrist" (Quem este quadro tem visto, jà vio de Espanha o Antechristo) ${ }^{12}$. The mordant rhyming couplet brilliantly illustrates the use of the imaginary and prophetic language for political purposes in the comparison of Philip IV's second in command with the Antichrist. It further shows the convergence and appropriation of prophetic language, the importance attached to certain issues, and pseudo-prophetic sources to which we have referred. The central figure, however, remains King João, not Sebastian. The eschatological rivalry between the two continued for a long time, and Sebastianism continued to exist in Portugal until the twentieth century ${ }^{13}$. The publicly visible polemics between the supporters of João and the supporters of Sebastian as messianic king came to a head in an article which appeared in the Gazeta de Lisboa in September $28^{\text {th }}$ of $1809^{14}$. The issue at hand in our article, that is to say, the debate between these two parties about who would be the Messianic emperor (of the end of times), however, was no doubt already debated when the documents included in BNP Cod. 798 were likely copied and compiled ${ }^{15}$.

In the miscellaneous manuscript we can distinguish between three types of texts: historical, doctrinal, and prophetical that, as we will see, are connected in some respects. We find a good number of texts that adhere to the Joanist position, but also some that claim that Sebastian is the chosen one. One of them, entitled "The curious book that contains the pros and cons of all that what the Sebastianists have written, by which it is shown everything that opponents of this opinion adduce, and it is followed by the demonstration of all foundations on which the Sebastianists set their hopes." ${ }^{16}$ The text initially presents arguments against Sebastianism in the way they would be formulated by its detractors, but then uses followed by a defense of Sebastianism ${ }^{17}$. The relationship between the two kings in the Sebastian discourse is clearly seen in one of the arguments in which a prophecy by Fray Gil is quoted about the "insperate ab insperato redimeris" and the interpretation thereof as João IV in which we find a prophecy by Fray Gil with a reference to the "insperate ab insperato redimeris" that is interpreted as João IV. The author argues that such an identification does not oppose Sebastianism, even though Sebastianists themselves claim that it implies that Sebastian 
is not alive. Rather, it claims that King João had redeemed and freed the Portuguese from their subjection to the "Foreign King," but Sebastian will come to fulfill another prophecy ${ }^{18}$ containing forecasts that have yet to come true. Another composition in the manuscript is entitled "Paper of Father Antonio Vieira about the hope on the King D. Sebastian"19, and contains Sebastianist texts. Remarkably, the paper, which precedes the "Moor of Granada," suggests that the manuscript was intentionally edited and compiled. This planned format is hinted at by the fact that some of its sections are shortened or lengthened. Furthermore, the author/compiler explicitly claims that he has omitted some parts of Vieira's original paper, such as the prophecies of Saint Francis of Paola ${ }^{20}$; the revelations of Soror Martha de Christo ${ }^{21}$; and the octave verses of Bocarro $^{22}$ that he has already mentioned in his "own" work, called the "Book of my miscellanies of historical news or historical miscellanies ${ }^{23}$. It is not clear, however, whether under "Historical miscellanies" refers to only this particular section ${ }^{24}$ or whether the author/compiler is referring the "Curious and interesting miscellaneous manuscript" as a whole. In the "Curious book," particularly after the section entitled "Prophecies" (Vaticinios) - which comes after the sayings of the Inquisition about the prohibition of the Trovas of Bandarra on f. $202 \mathrm{r}-{ }^{25}$ we find among other materials, the prophecies of Saint Francis of Paola ${ }^{26}$ and the octave verses of Bocarro ${ }^{27}$.

7 Whereas Sebastianism is mainly referenced in the texts mentioned in the previous paragraph, most of the manuscript texts defend the Joanists' support of conversos. An important distinguisher of Joanists is their solidarity with the conversos and willingness to protect them, in opposition to Sebastianists' attitudes that were much more combative in this regard. The hostile animosity between the two groups centered around this issue and eventually ending with the victory of Sebastianism, and the preservation of Joanism in text alone ${ }^{28}$. It is thus not surprising to find a defense of these accusations in texts supporting João in the present miscellaneous manuscript. After a long enumeration of various historical reports (that range from facts related to the monarchy and the war campaigns to the discoveries of scientific character and curiosities) comes the description of the historical events of December $1^{\text {st }}, 1640$ when a group of men (about thirty or forty men known as os conjurados) overthrew the Spanish power in the country by attacking and killing its representatives, including the secretary of the Spanish King, Philip IV, Miguel de Vasconcellos, and "proclaimed" João as King João IV of Portugal ${ }^{29}$. What follows are a number of texts connected to João's ascension to the throne that emphasize the divine nature of the event. We have already mentioned above the Évora panels and the oaths which are among those from the three kingdom states to King João ${ }^{30}$, and a number of references to battles between Spain and Portugal that give the victory to the Portuguese ${ }^{31}$. More enlightening is one such text by Francisco Rebelo Homem, city councilor of Lisbon, who gives the king the key to the city, and says that "his election was more divine than human, and with it he reached the true dominion and peaceful possession of a kingdom canonized by the same God." 32 In another, the Bishop of Elvas claims that the King of Castile usurped the independent sovereign the power of God ${ }^{33}$.

These texts praising King João seem to be connected to other Joanist documents in the miscellaneous manuscript which discuss the role of conversos. Some of the views strongly suggest that the author/compiler aimed to counterbalance the attacks of the Sebastianists. The military achievements of the Portuguese are followed by judicial sentences (auto da fé), such as the burning of the Jew Gaspar Lopez Pereira in Lisbon in $1682^{34}$. A summary of the inquisition is given in great detail and special emphasis is 
placed on the stubbornness of the Jew who, after converting to Christianity, changed his mind and returned to Judaism, making burning at the stake inevitable. In an additional text, the Jesuit priest Antonio Vieira expresses his political opinion of conversos to King João in 1644, namely that they should be allowed in the kingdom ${ }^{35}$. Moreover, Vieira is known for his interpretation of Bandarra's prophecies that argues that they refer to João, not Sebastian. He used these and other ideas to lay the foundations of a claim of a Fifth Empire in Portugal, marked by João's reign. All these texts are collected in the present work ${ }^{36}$.

The miscellaneous manuscript also includes Vieira's defense against accusations of heresy and in support of the conversos. At the end of the "Curious Book", we find Vieira's petition to the Inquisition, explaining his weak health, and his right to deny the charges imputed to him before the tribunal ${ }^{37}$. Included is a defense of his work on the Fifth Empire ${ }^{38}$ and Vieira's counterarguments to nine "propositions" or charges against him $^{39}$. Overall, Antonio Vieira is portrayed as a follower of the true Catholic Church $^{40}$, however contrary to the sentiments in his previous work, Joanism is portrayed in this text as a continuation of Sebastianism and is hostile towards the conversos.

10 The prophecy of the "Moor of Granada" ${ }^{11}$ follows the "Paper of Father Antonio Vieira about the hope on the King Don Sebastian," and is in fact the first prophecy that is not found in what here seems to be Vieira's original work ${ }^{42}$. Our prophecy and the subsequent text "Moiro (sic) ${ }^{43}$ Abel," are the only texts that fall between Vieira's "Paper" and the trial description that defend Sebastianism. Significantly, the prophecy is already announced earlier in the manuscript. The foreword to Vieira's "Paper" reads, "See now the prophecies of the "Moor of Granada," which will be found after the treatise by Father Vieira that comes next." "That is to say, the author/compiler of the "Curious Book" directly references to the "Moor of Granada" in connection with the "Paper" in the section entitled "Prophecies" (Vaticinios). It is difficult if not impossible to know the author's reason for citing Vieira, but it can nevertheless be fruitful to analyse the use of sources of Arabic and Islamic origin in order to shed light upon the functions and the rhetorical appeal of the prophecy of the "Moor of Granada".

\section{The Prophecy of the Moor of Granada}

11 We will start our study of the prophecy with the analysis of a) language, b) minoritymajority relations in Christian Iberia and Portugal, and c) messianic-political history of Spain and Portugal. Portuguese is the dominant language in the book, however the approach to non-Portuguese texts varies. We find both Portuguese texts that claim to be translations from the original Spanish, such as the aforementioned prophecies of Francisco de Paola, and other texts that remain untranslated in Castilian, as with the prophecy of Frade Bento Aragonez to Ferdinand the Catholic when he was in Granada in $1491^{45}$. In the prophecy of the "Moor of Granada," the references to language are related to issues of authenticity; Muslims consider Arabic to be the sacred language of Islam and of God's revelation to Muhammad, thus its use in a forecast of messianic content gives the prophecy an aura of sacredness. The implicit claim is that prophecy has Islamic origins and that the reverence of Muslims for the Arabic language should convince the reader that the original content had remained unaltered. 

belief in a universal and shared truth by Christians, Muslims and Jews that often needs to be "translated." ${ }^{46}$ Throughout the manuscript, messianic hopes for the kings of Portugal are predicated by Christian prophecies as well as Muslim ones. Father Antonio Vieira emphasizes in the "Eight Fundament" of the "Paper" that the coming of King Sebastian is proven by Muslim traditions; God didn't deprive Muslims from having "science," that is to say, knowledge, indeed ${ }^{47}$. In this context, "translation" is understood as the disclosure of hidden prophetic knowledge and it is here where Muslims are often portrayed by Christians as key figures in its transmission. The argument is that Muslims have exclusive access to a certain type of knowledge, in many cases prophetic, that only they can explain to their co-religionists and to Christiansnot only ordinary Christians, but also kings. Hence, the "Moor of Granada" acts as an interpreter of prophecies for the Christian kings, like the wise Granadan "Moro" philosopher in the Chronicle of Pedro I by Don Pedro de Ayala, who explains the meaning of Merlin's prophecies to King Pedro in $1369^{48}$. Here, the prophecy does not contain direct references to the Arabic language, however the figure of the Moor still acts as a bearer of the divine message, for example, when he designates Portugal as God's chosen kingdom that "will be victorious and not vanquished," and he says of its king that God gave him power "until what had to happen would come to manifest itself," referring to the promise of the Fifth Empire ${ }^{49}$.

ada, where the military and religious struggle between Christianity and Islam in the peninsular territories between the early fifteenth and seventeenth century (ending with the expulsion of the Moriscos) was fought, takes a central place in Ayala's example, and in our prophecy. It is easy to understand that the fall of the Muslim city in the Christians' hands on January $1^{\text {st }}, 1492$ held great significance to the members of the two communities and that they attached great significance, too, to references to these historical events. The military struggle provides a chance not only to defeat the religious Other on the battlefield, but also to acquire new knowledge that so far was only accessible by the opponents. Father Antonio Vieira argues in the "Eight Fundament" of the "Paper" that when Muslims defeated the Portuguese, they were to be prouder of the victory against Portugal, we know that they did not hesitate to confess to the defeated Portuguese this fatal and future return with which our arms would not only subject that small part of Africa, but all Muslim power." "A Muslim alcalde" we further read "in whose power they were (here the reference is to two Portuguese men, Francisco de Meneses and Jorge de Albuquerque), had often told them that in their Mostasfos a tradition was found that a snake would be born in Portugal ... and would master most of the world ${ }^{50}$.

The Muslims' victory in the famous and mythic battle that marked the death of three kings led to the rise of Sultan Ahmad Al-Mansur and the Sa'did dynasty, and turned Morocco in a great power in the seventeenth century. Despite the triumph Muslims were fully aware that they would ultimately be defeated by Portugal. The knowledge of the coming of a Portuguese king was widespread and even reached India. There, a local Muslim became frightened after hearing the name of the King of Portugal (i.e. Sebastian), because the "Mostafos (i.e. of Muslim origin) predicted that a king called Sebastian would destroy their sect." ${ }^{11}$ The powerful image is that of Muslims who finally bow to Christians and who, in our prophecy, rejoice together with the Christians, because the return of a Portuguese king signals the coming of the Encubierto,

Hamsa, 6 | 2020 
who would "illuminate the world." ${ }^{52}$ We have found no evidence in our sources that authentic Muslim prophecies were used. The references therefore serve as a rhetorical figure-the "rhetorical Muslim"- which attests to the truth and final victory of Christianity.

15 A series of references in this miscellaneous manuscript also connect kinship with the city of Granada. In them we find the anxiety and hopes that arise from the last and decisive battle for the control of the Iberian territories, which is in line with the anxiety and hopes found in prophecies dealing with the last battle between Islam and Christianity at the End of Times. We can understand from this perspective the various quotations of a certain Frade Bento Aragonez to Ferdinand the Catholic during the siege of Granada in 1491. It is unclear to whom these texts should be attributed. On the one hand, the "Second Argument" of this edition of the "Paper," (based on a nineteenth century edition of a number of manuscripts) contains the prophecies in Castilian of a certain "Frei João de Rozacelça, religioso de S. Bento Aragonês, as quais mandou a El Rei D. Fernando estando em Granada." We find a similar text within the "Curious Book" but, at this point, our miscellaneous manuscript does not include this text and, thus, misses the identification with Rocacelsa ${ }^{53}$.

We could infer that the two texts were likely written by the same person when we examine a longer version of this prophecy preserved in a manuscript from the Biblioteca de Elvas ${ }^{54}$. One of the texts contains a miscellaneous work of prophecies copied in 1703 (Ms. 354), including the "Compendium of Old and Modern Prophecies and Forecasts that Tell of the End of the Sect of Muhammad and the Liberation of Jerusalem and Palestine" by the Granadan presbyter Don Cristóbal López de Cañete (1567-1637). It describes a friar of the Order of St. Benedict who sent a prophecy to Ferdinand in Granada "when the latter was about to die in Aragon, the region where he was born." ${ }^{55}$ Bound within the same miscellaneous, we read about another prophecy written by a religious man from São Bernardo de Aragon sent to the King Don "Hernando" while in Granada ${ }^{56}$. One might only wonder how it is possible that the fourteenth-century Rocacelsa (probably the well-known Friar Jean de Roquetaillade) "sent" a prophecy to Ferdinand ${ }^{57}$. We are therefore very likely dealing with the Benedictine monk at Montserrat, Fray Benito (Martínez) de Aragón, hermit of Montserrat and well known for his prophetical visions ${ }^{58}$. This assumption is supported by the facts that Benito de Aragón lived and worked around $1500^{59}$, and that the Montserrat Abbey had close relations to the Catholic Kings. Furthermore, the report of the conquest of Granada by Serra y Postius states, "the Virgin of Monserrate also cooperated very much in the achievement of this victory ... in that same year of 1492 both Don Ferdinand and Doña Isabel climbed the portentous mountain and gave thanks [to the Virgin]." ${ }^{00}$ If this identification is correct, however, it would speak against Benito de Aragón authoring the text as he took the vows to become a Benedictine in 1494 , and therefore could not have written the prophecy on his deathbed in 1491 . We are left then with only conjectures about the identity of the Benedictine friar.

What stands out in the prophecy is the connection between political change and the relations between the Christian and Muslim communities. The capture of Granada serves as a turning point from which Christian dominion will result first by turning Muslims into a minority, then converting the remaining Muslims, so that their expulsion is made explicit. Thus, the prophecy of San Nicolau Factor in Francisco Navarro de Xàtiva's Politica Espanhola (1619) (and again in the aforesaid work by López 
de Cañete) reads "after the Muslim sect in Spain would have been destroyed, and all Muslims had been driven out, it will be the recovery of the Holy Land and war will be proclaimed." 61 And it is precisely the question of who will be victorious, Spain or Portugal, which was the most heated issue in the messianic-political history of the two kingdoms. We have already mentioned a number of forecasts of the destruction of the Muslims, sometimes put in the mouth of the Muslims themselves, and also with regard to Muslim knowledge of astrological predictions. For example, a scholar such as the astrologer Abu Ma'shar (787-886) is mentioned in fifteenth-century sermons of the bishop of Barcelona, Martín García ${ }^{62}$ and, again, in López de Cañete's work. Muslims and predictions, as we have seen, converge in Spanish history, in the history of Granada and, in particular, in the figure of the Muslim who is at the same time praised for his knowledge and despised for his faith.

In turn, Spanish history had to be appropriated too, if one wanted to fulfil the Portuguese's messianic hopes. In the "Defense of the Book Fifth Empire," included in our manuscript, Bandarra claims that the expected emperor is the messiah who is awaited by the Jews [sic]). The fact that he must be Portuguese, and a descendant of Ferdinand the Catholic and successor of the King Alfonso Henriquez, reiterates the bonds between the two countries ${ }^{63}$. However, we do not find appropriation only, but also separation between Spain and Portugal. In this way, we find the Queen of Castile, Doña Urraca, predicting that "the kingdom of Portugal will never be united to that of Castile." ${ }^{64}$

The prophecy of the "Moor of Granada" thus reveals both the appropriation and the rejection of the history of Spain, of its relations with Islam and Muslims and its entanglement with a discourse that claims that the future Universal Emperor will be of Portuguese descent. It will later be used as well to attack Sebastian's followers in AntiSebastianismo, ou, Antidoto contra vários abusos ${ }^{65}$, an anonymous work mentioned in the issue of the Gazeta de Lisboa. In the announcement of the imminent publication of this work, we read that in it one finds "the denial of the coming of King Sebastian; it contains the prophecies that serve as basis for the fervent supporters of this coming, which are analyzed and refuted." ${ }^{66}$ These claims are not only the object of controversy with the Spaniards, but, as we have just observed, there is also an ongoing struggle between different factions within Portuguese society as to who the king destined to occupy this position is. The prophecy of the "Moor of Granada" is among the texts that will be reinterpreted to oppose the Sebastianists, showing how tensions of a religious but also a national character are articulated around the figure of the Muslim and its epistemological branches alongside the contours that we have attempted to outline so far.

\section{The Messianic-Political History of Spain and Portugal}

Our study shows that prophecies attributed to Muslims had a surprisingly long life in the western parts of the Mediterranean, in our case the Spanish kingdoms and Portugal. Starting in the fourteenth century we find that Christian and Muslim prophecies-be they original, modified, updated, or outright forged prophecies-were used in a war of words and arms. In Spain, these parties originally consisted of Muslim minorities and Iberian Christians, but from the sixteenth century onwards PortugueseMoroccan relations started to play a role as well. This eventually led to compilations 
such as manuscript 798 of the National Library of Portugal. As we have seen, the said manuscript, compiled by an anonymous author/copyist, includes among its manifold sources about Sebastian and João a number of sources in which references are made to Islam and Muslims, including the prophecy that is the subject of our study. We have argued that they probably go back to earlier compilations in which these prophetical texts, or references to Christian prophetical texts were found. In no case have we have found that authentic Muslim prophetical materials were used, except in the compilation of López de Cañete, which references a prophecy found in 1588 in the city of Granada ${ }^{67}$. That prophecy may have been the work of Moriscos, an origin suspected but not confirmed at the time. The prophecy attributed to the "Moor of Granada" seems to be of a Christian background and probably written much later than 1510 , the date mentioned in the manuscript ${ }^{68}$. We can therefore safely assume that the Granadan Muslim is a literary device, a "rhetorical Muslim," introduced to increase its prestige as testimony of the opponents themselves. The fall of such cities as Granada, was because of the great political and symbolic importance to different groups. The fall of Granada was seen by some groups in the Iberian Kingdoms in the early $16^{\text {th }}$ century as a decisive step in a general defeat of the Muslims and the liberation of Jerusalem ${ }^{69}$. This may explain why prophecies attributed to a Granadan Muslim were prone to be deemed of importance. Furthermore, seemingly insignificant moments, places and persons could in later times be ascribed an important meaning. The defeat of Sebastian in Morocco in 1578 turned into a religious-political "master narrative" of suffering and victory in Sebastianist and Joanist circles in Portugal well into the twentieth century, and, as our manuscript shows, continued to make discursive use of Muslims and Islam. Our analysis does not take Muslim prophecies into account, simply because they did not appear to play a role, but that is not to say that such prophecies did not exist, on the contrary ${ }^{70}$.

\section{BIBLIOGRAPHY}

\section{Archival Sources}

Biblioteca Nacional de Portugal [BNP], Cod. 402; MS 798.

Bibliography and printed sources

ARGAÍZ, Gregorio de, La Perla de Cataluña. Historia de Nuestra Señora de Monserrate, Madrid, Imprenta de Andrés García de la Iglesia, 1677.

AYALA, Don Pedro de, Crónicas de los Reyes de Castilla Don Pedro, Don Enrique II, Don Juan I, Don Enrique III, Vol. 1, Madrid, Imprenta de Don Antonio de Sancha, 1779.

BARCELÓ, Carmen, LABARTA, Ana, “'Tawq al-hamama'. Un muwaššah apocalíptico,” in Traducir el mundo árabe. Homenaje a Leonor Martínez Martín, eds. Mònica Rius et al., Barcelona, Universitat de Barcelona, 2014, pp. 93-131.

BATAILLON, Marcel, Erasmo y España. Estudios sobre la historia espiritual del siglo XVI, México, Fondo de Cultura Económica, 1995. 
BESSELAAR, José van den, António Vieira: o Homem, a Obra, as Ideias, Lisboa, Instituto de Cultura e Língua Portuguesa, 1981.

BOISVERT, Georges, “La ‘Guerra Sebástica' à Lisbonne en 1810. Les dessous de la polémique," Arquivos do Centro Cultural Português, 19 (1983), pp. 671-685.

CANTEL, Raymond, Prophétisme et Messianisme dans l'œuvre d'António Vieira, Paris, Ediciones Hispano-Americana, 1960.

CARRASCO URGOITI, Soledad, El moro de Granada en la literatura. Del siglo XV al XIX, Madrid, Revista de Occidente, 1956.

COLOMINAS APARICIO, Mònica, "Profecía, conversión y polémica islamocristiana en la Iberia alto-moderna (siglo XV). Alfonso de Jaén y el círculo del obispo don Martín García," in Visiones imperiales y profecía. Roma, España, Nuevo Mundo, eds. Stefania Pastore, and Mercedes GarcíaArenal, Madrid, Abada Editores, 2018, pp. 51-77.

FONSECA, António Monteiro da, Sobre o sebastianismo. Um curioso documento do começo do século XVIII, Coimbra, Coimbra Editora, 1959.

GARCÍA-ARENAL, Mercedes, "Granada as a New Jerusalem. The Conversion of a City," in Space and Conversion in Global Perspective, eds. Giuseppe Marcocci et al., Leiden, Brill, 2015, pp. 15- 43.

GARCÍA-ARENAL, Mercedes, WIEGERS, Gerard (eds.), The Expulsion of the Moriscos of Spain. A Mediterranean Diaspora, Leiden, Brill, 2014.

Gazeta de Lisboa, 102 (28-09-1809).

GIVENS, Bryan, "Sebastianism in Theory and Practice in Early Modern Portugal," in Braudel Revisited. The Mediterranean World 1600-1800, eds. Gabriel Piterberg, Teofilo F. Ruiz, and Geoffrey Symcox, Toronto, University of Toronto Press, 2010, pp. 127-150.

GREEN-MERCADO, Mayte, "Morisco Prophecies at the French Court (1602-1607)," Journal of the Economic and Social History of the Orient, 61 (2018), pp. 91-123.

HERMANN, Jacqueline, “A Cidade do Paraíso Terrestre-O movimento sebastianista da Serra do Rodeador, Pernambuco, na primeira metade do século XIX," in De sertões, desertos e espaços incivilizados, org. Angela Mendes de Almeida, Berthold Zilly, and Eli Napoleão de Lima, Rio de Janeiro, MAUAD/FAPERJ, 2001, pp. 243-260.

KONINGSVELD, Pieter Sjoerd van, WIEGERS, Gerard, The Sacromonte Parchment and Lead Books. Critical Edition of the Arabic Texts and Analysis of the Religious Ideas. Presentation of a Dutch research project, Granada, 19 March 2019,19.00-21.00 hours. With images of the original Lead Books and the Parchment, s.l, Avondrood, 2019.

KONINGSVELD, Pieter Sjoerd van, WIEGERS, Gerard, “The Parchment of the 'Torre Turpiana'. The Original Document and its Early Interpreters," Al-Qanțara. Revista de Estudios Árabes, 24.2 (2003), pp. 327-358.

LAVADINHO, Domingos, Manuscritos e outros documentos da biblioteca municipal de Elvas, vol. 2, Elvas, Tipografía Progresso, 1948.

LEITÃO, José Carlos Vieira, King of whose country? A 1920's Sebastianic debate, unpublished MA paper Religious Studies, University of Amsterdam 2016.

LÓPEZ DE CAÑETE, Cristóbal, Compendio de los pronosticos y baticinios antiguos y modernos que publican la declinación general de la secta de Mahoma, y libertad de Hierusalem y Palestina, Granada, Apud Francisco Heylan, 1630. 
MILHOU, Alain, “Esquisse d'un panorama de la prophétie messianique en Espagne (1482-1614). Thématique, conjoncture et fonction," in La prophétie comme arme de guerre des pouvoirs (XVe-XVIIe siècles), ed. Auguste Redondo, Paris, Presse de la Sorbonne Nouvelle, 2000, pp. 11-29.

MIQUEL ROSELL, Francisco, Inventario General de Manuscritos de la Biblioteca Universitaria de Barcelona, Volumen 1 (1-500), Madrid, Direcciones Generales de Enseñanza Universitaria y de Archivos y Bibliotecas, 1958.

MONTOZA COCA, Manuel, Los sermones de don Martín García, obispo de Barcelona. Edición y estudio, PhD thesis., 2 vols, Universitat de Barcelona, 2018.

OLIVEIRA, Eduardo Freire de, Elementos para a historia do municipio de Lisboa, $1^{\underline{a}}$ parte, Tomo IV, Lisboa, Typographia Universal, 1888.

Padre António Vieira. Obra Completa, dir. José Eduardo Franco e Pedro Calafate, Tomo IV, vol. I, Escritos Políticos, coord. António Pedro Barbas Homem, Lisboa, Círculo dos Leitores, 2014.

SARAIVA, António José, “António Vieira, José Menasseh ben Israel et le Cinquième Empire”, Studia Rosenthaliana, VI (1972), pp. 25-57.

VALDEZ, Maria Ana Travassos, Historical Interpretations of the "Fifth Empire". The Dynamics of Periodization from Daniel to António Vieira, Leiden, Boston, Brill, 2011.

VALENSI, Lucettte, "Comment prouver la mort du roi. Le cas de Sébastien de Portugal," Les Cahiers du Centre de Recherches Historiques, 5 (1990), pp. 1-9, DOI: 10.4000/ccrh.2879.

VIEIRA, Padre Antônio, De profecia e inquisição, Brasília, Senado General 1998.

WIEGERS, Gerard, "Jean de Roquetaillade's Prophecies among the Muslim Minorities of Medieval and Early Modern Christian Spain. An Islamic Version of the "Vademecum in tribulation," in The transmission and dynamics of the textual sources of Islam. Essays in honour of Harald Motzki, eds. Nicolet Boekhoff-van der Voort, Kees Versteegh, and Joas Wagemakers, Leiden, Brill, 2011, pp. 229-247.

YEPES, Fray Antonio de, Coronica general de la Orden de San Benito, Patriarca de Religiosos, Vol. 4, Valladolid, Francisco Fernández de Córdoba, 1613.

ZARAGOZA Y PASCUAL, Ernest, Els ermitans de Montserrat. Història d'una institució benedictina singular, Barcelona, Publicacions de l'Abadia de Montserrat, 1993.

\section{APPENDIXES}


The Prophecy of the Moor of Granada 


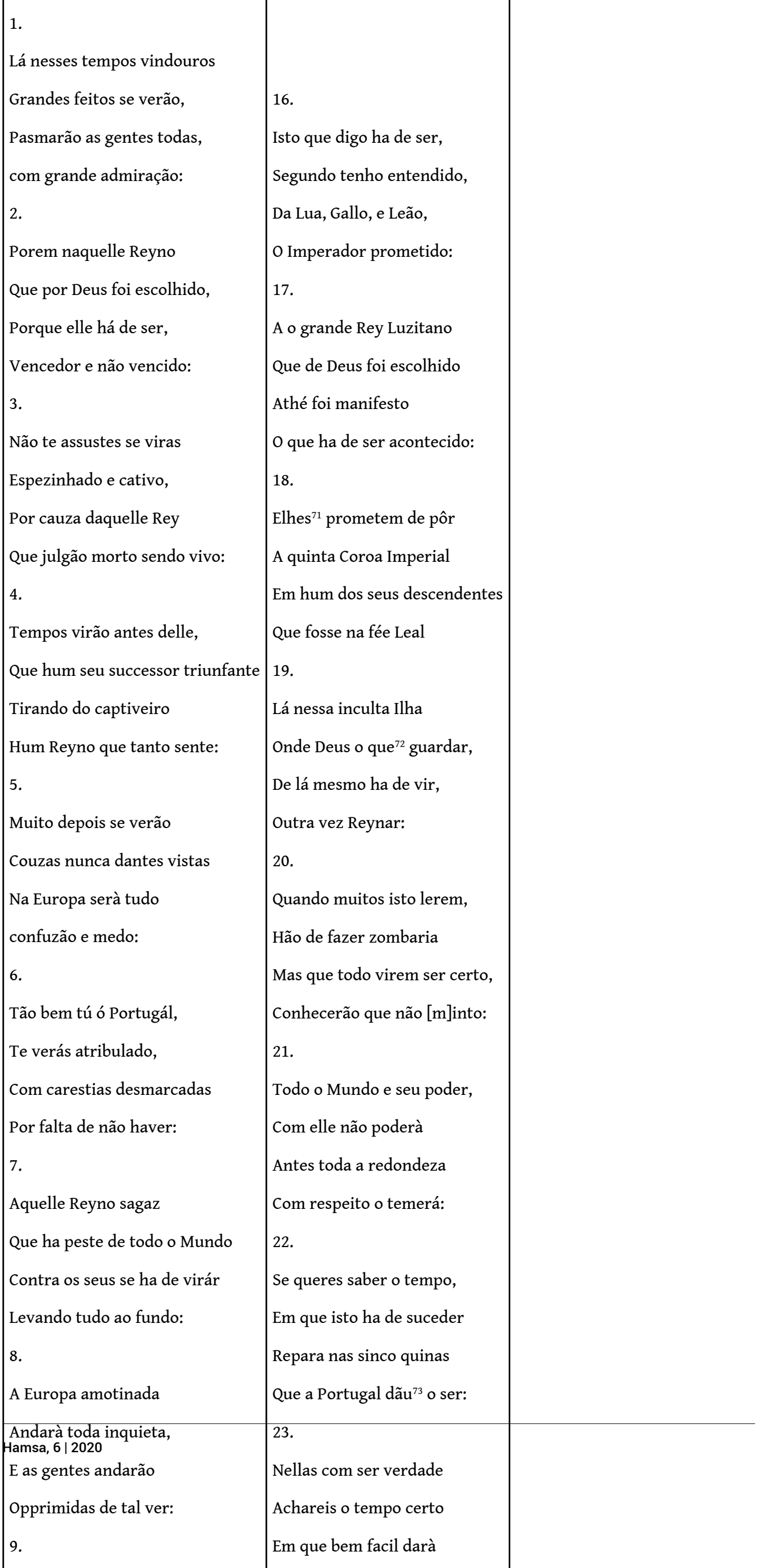


Possible author: Padre Manuel de Escobar, Jesuit (José Agostinho Macedo, Os Sebastianistas, Lisboa, Officinas Antonio Rodrigues Galhardo, 1810, p. 14).

\section{NOTES}

1. Alain Milhou, "Esquisse d'un panorama de la prophétie messianique en Espagne (1482-1614). Thématique, conjoncture et fonction," in La prophétie comme arme de guerre des pouvoirs (XVe-XVII siècles), ed. Auguste Redondo, Paris, Presse de la Sorbonne Nouvelle, 2000, pp. 11-29, p. 13. The authors thank the anonymous reviewers and the editors of Hamsa for their useful remarks. A previous version of this paper was presented at the workshop "Connected Histories? Expectations of the Last Days in Islam, Judaism and Christianity from the 15th to the 17th Centuries," Martin-Luther-Universität Halle-Wittenberg/Franckesche Stiftungen, Halle (Germany), July, 2018. We thank the organizer, Damien Tricoire and the participants for their comments.

2. Gerard Wiegers, "Jean de Roquetaillade's Prophecies among the Muslim Minorities of Medieval and Early-Modern Christian Spain. An Islamic Version of the "Vademecum in tribulation," in The transmission and dynamics of the textual sources of Islam. Essays in honour of Harald Motzki (Islamic history and civilization, 89), eds. Nicolet Boekhoff-van der Voort, Kees Versteegh, and Joas Wagemakers, Leiden, Brill, 2011, pp. 229-247.

3. See inter alia, Marcel Bataillon, Erasmo y España. Estudios sobre la historia espiritual del siglo XVI, México, Fondo de Cultura Económica, 1995; Mercedes García-Arenal, "Granada as a New Jerusalem. The Conversion of a City," in Space and Conversion in Global Perspective, eds. Giuseppe Marcocci et al., Leiden, Brill, 2015, pp. 15-43.

4. See Mercedes García-Arenal and Gerard Wiegers (eds.), The Expulsion of the Moriscos of Spain. A Mediterranean Diaspora, Leiden, Brill, 2014.

5. Bryan Givens, "Sebastianism in Theory and Practice in Early Modern Portugal," in Braudel Revisited. The Mediterranean World 1600-1800, eds. Gabriel Piterberg, Teofilo F. Ruiz, and Geoffrey Symcox, Toronto, University of Toronto Press, 2010, pp. 127-150, p. 130.

6. Lucettte Valensi, "Comment prouver la mort du roi. Le cas de Sébastien de Portugal," Les Cahiers du Centre de Recherches Historiques 5 (1990), pp. 1-9 ; p. 6. http://journals.openedition.org/ ccrh/2879; DOI: 10.4000/ccrh.2879. She refers in particular to Vieira's work, which we will study below.

7. B. Givens, "Sebastianism ...," p. 135.

8. Biblioteca Nacional de Portugal [henceforth BNP], MS 789, ff. 253r-v.

9. The title of the work reads, "miscelaneas curiozas e interesantes em manuscrito," - BNP, Cod. 798, fl. I. The spelling and word diacritics do not always follow the conventions of modern Portuguese. With very few exceptions, we keep here the original rendering, as well as in the edition of the prophecy included in the Appendix.

10. BNP Cod. 798, ff. 25r-26v.

11. BNP Cod. 798, f. 25r: "muy bien pulidas e ornadas."

12. BNP Cod. 798, f. 25r.

13. José Carlos Vieira Leitão, King of whose country? A 1920's Sebastianic debate. Unpublished MA paper Religious Studies, University of Amsterdam 2016.

14. Gazeta de Lisboa, No. 102, 28-09-1809, https://hdl.handle.net/2027/hvd.hxihc3.

15. One of the latest dates mentioned in the miscellaneous manuscript is 1788 , to be found on $\mathrm{f}$. 220r. The debate within Sebastianism itself and as to whether or not to expect the coming of King Sebastian was alive at the time, according to Jacqueline Hermann, because of the expulsion of the Jesuits from Portugal, whose activities were closely linked to such a hope. We see the circulation 
of texts examining the foundations of Sebastianism (BNP (but the reference is to the older BNL) Cod. 402, 1712) or "The answer given in 1714 to the one who asks the following question: Should we still wait today for the lord King Dom Sebastian? Brought to light by an anonymous author in the year of 1823." Signed: F.L.B.M." ( $i$ “Resposta q se deu em 1714. Aquem fez a seguinte pergunta - “devemos ainda hoje esperar pelo Senhor Rey dom Sebastião? Dada à lux por hum anonimo no ano de 1823." Signed: F.L.B.M.") edited in Coimbra by A. Fonseca Montero in 1959 under the title, Sobre o sebastianismo. Um curioso documento do começo do século XVIII. See Jacqueline Hermann, "A Cidade do Paraíso Terrestre-O movimento sebastianista da Serra do Rodeador, Pernambuco, na primeira metade do século XIX," in De sertões, desertos e espaços incivilizados, org. Angela Mendes de Almeida, Berthold Zilly, and Eli Napoleão de Lima, Rio de Janeiro, MAUAD/FAPERJ, 2001, pp. 243-260, p. 246 n. 11. On the "Sebastian Wars," see Georges Boisvert, "La 'Guerra Sebástica' à Lisbonne en 1810. Les dessous de la polémique," Arquivos do Centro Cultural Português 19 (1983), pp. 671-685.

16. Livro das coizas mais notaveis que tenho lido á cerca dos fundamentos que tem os Sebastianistas, porque afirmarem em que hè vivo e ha de vir o serenissimo Rey Dom Sebastião, BNP Cod. 798, ff. $107 \mathrm{r}-221 \mathrm{v}$. The composition has no clear end but we argue it runs until f. $221 \mathrm{v}$, with additions made in 1729 to an original dating from 1659 when some prophecies of Bandarra are found and copied, BNP Cod. 798, f. 157v.

17. BNP Cod. 798, f. 113r and ff.

18. "Sic Africa debelabitur, Imperium Ottomanum Ruet, Ecclesia Martiribus decorabitur, Bisantium subuertetur, Domus Dei recuperabitur," BNP Cod. 798, ff. 118r-v.

19. BNP Cod. 798, ff. 222r-252v: "Papel do Padre Antonio Vieira sobre a esperança em el Rey D. Sebastião." This particular text and also others noted below have been edited on commemoration of Vieria's 300-year centenary of his death (Padre Antônio Vieira, De profecia e inquisição, Brasília, Senado General 1998. In this edition the "Paper" corresponds, with some differences, with Vieira's "Discurso em que se prova a vinda do Senhor Rei D. Sebastião," on pp. 111-172. See on Vieira's life and work: Maria Ana Travassos Valdez, Historical Interpretations of the "Fifth Empire". The Dynamics of Periodization from Daniel to António Vieira, S.J. , Leiden, Boston, Brill, 2011: and, among other studies, Raymond Cantel, Prophétisme et Messianisme dans l'œuvre d'António Vieira, Paris, Ediciones Hispano-Americana, 1960; José van den Besselaar, António Vieira: o Homem, a Obra, as Ideias, lisboa, Instituto de cultura e língua portuguesa, 1981; António José Saraiva, “António Vieira, José Menasseh ben Israel et le Cinquième Empire”, Studia Rosenthaliana VI (1972), pp. 25-27.

20. BNP Cod. 798, f. $228 \mathrm{v}$.

21. BNP Cod. 798 , f. $239 \mathrm{v}$.

22. BNP Cod. 798 , f. $244 \mathrm{v}$.

23. See for the references to the "Livro das minhas Miscelaneas de noticias historicas" or "Miscelaneas históricas," ff. 228v-229r, f. 233r, f. 239v, f. $244 \mathrm{v}$ and for the reductions and additions to the current edition (Vieira, De profecia e inquisição, cf. p. 154 with f. 244r; p. 163-165 with f. $248 \mathrm{v}$; and p. 166 with f. $249 \mathrm{r}$.

24. BNP Cod. 798, ff. 202r-221v.

25. BNP Cod. 798, f. 198 r.

26. BNP Cod. 798, ff. 213r-v.

27. BNP Cod. 798, ff. 215v-216v.

28. B. Givens, "Sebastianism ..."

29. BNP Cod. 798, f. 14 and ff.

30. BNP Cod. 798, f. 27v.

31. BNP Cod. 798, ff. 40r-v.

32. "a sua eleição foi mais divina que humana, e com ella alcançou o verdadeiro dominio e pacífica posse de um reino canonizado pelo mesmo Deus," f. 22v. See also, Eduardo Freire de Oliveira, Elementos para a historia do municipio de Lisboa (1 $1^{\underline{a}}$ parte, Tomo IV), Lisboa, Typographia 
Universal, 1888, p. 415, https://archive.org/stream/elementosparaah12olivgoog\#page/n433/ mode/2up/search/pelo+mesmo+deus.

33. BNP Cod. 798, f. 24 r.

34. BNP Cod. 798, ff. 41r-45r.

35. BNP Cod. 798, ff. 51r-74v. "Parecer político que se deo ao Senhor Rey Dom Joaõ o $4^{\circ}$. sobre o argumento do Reyno, concluindo em que se concinta nelle aos Christãons Novos. Per lo Padre Antonio Vieira da Companhia de Jezus anno de 1644," f. 51r.

36. BNP Cod. 798, ff. 75r-106v: "Esperanças de Portugal $5^{\circ}$ Imperio do Mundo: Primeira e segunda vida de el Rey Dom João $4^{\circ}$ escrita por Gonzalo Annes Bandarra, e comentadas por lo Padre Antonio Vieira da Companhia de Jezus, cujo comento remeteo ao Bispo do Japão o Padre Andrè Fernandes, em 29 de Abril de 1659."

37. BNP Cod. 798 , ff. 258r-271v.

38. BNP Cod. 798 , ff. $272 \mathrm{r}-307 \mathrm{v}$.

39. BNP Cod. 798, ff. 308r-311v. See also Vieira, De profecia, 3-61.

40. BNP Cod. 798, f. 259r.

41. BNP Cod. 798 , ff. 253 r-v.

42. In the consulted edition, p. 172 and in the manuscript f. 252v, it is clear indicated that the "Paper" has come to an end. The prophecy is not included in Vieira's texts about king Sebastião, in which he transcribed several other prophecies ("vaticínios"), see Padre António Vieira. Obra Completa, dir. José Eduardo Franco e Pedro Calafate, Tomo IV, vol I, Escritos Políticos, coord. António Pedro Barbas Homem, Lisboa, Círculo dos Leitores, 2014, pp. 137-256. The preceding assessment follows the important comment made by one of the anonymous reviewers. The authors have not been able to consult the said edition themselves.

43. BNP Cod. 798, ff. 255r-256r.

44. "Vejase agora as Profecias do Mouro de Granada, que se acharão depois deste papel seguinte do Padre Vieira," BNP Cod. 798, f. 221v.

45. "estando sobre Granada no Anno de 1491," BNP Cod. 798, f. 140v and mentioned on f. $124 \mathrm{v}$ as well.

46. For a discussion of the "diplomatic" functions of Morisco prophecies working at the crossroads of interreligious and political discourses in the Mediterranean, and hence of "translation," see Mayte Green-Mercado, "Morisco Prophecies at the French Court (1602-1607)," Journal of the Economic and Social History of the Orient 61 (2018), pp. 91-123.

47. BNP Cod. 798, f. 249r.

48. Don Pedro de Ayala, Crónicas de los Reyes de Castilla Don Pedro, Don Enrique II, Don Juan I, Don Enrique III, Vol. 1, Madrid, Imprenta de Don Antonio de Sancha, 1779, pp. 537-544.

49. "Porem naquelle Reyno que por Deus foi escolhido porque elle ha de ser vencedor e não vencido" (second stanza); "A o grande Rey Luzitano/Que de Deus foi escolhido/Athé foi manifesto/o que ha de ser acontecido" (seventeenth stanza); "Elhes prometem de pôr a quinta Coroa imperial" (eighteenth stanza).

50. BNP Cod. 798, f. 249r: "Quando elles devião estar mais soberbos com a maior victoria de Portugál, nos consta que não duvidava o confesár aos mesmos Portugueses vencidos, esta volta fatál, e futura, com que as nossas armas, não só havião de sujeitar aquella piquena parte de Africa, mas todo o poder Maometano" “...hum Alcaide Mouro, em cujo poder estiverão, lhes disera, por muitas vezes, que em seus Mostasfos tinha huma tradição e hà que no Reyno de Portugál nasceria huma cobra, ... e será senhor da mayor parte do Mundo."

51. BNP Cod. 798, f. 249v: "porque os nossos Mostafos dizem, que hum Rey desse nome Sebastião, ha de destruir a nossa Ceita."

52. “A vinda do Lusitano/Pouco depois tardará/Virá o Rey encuberto/que luz ao mundo dará" (twenty-fifth stanza); "Todos hão de alegrarse,/Sentindo novo conforto/Vendo entrar em Portugal/Vivo, quem concederão morto" (twenty-seventh stanza). 
53. BNP Cod. 798, ff. 140v-141r.

54. We would like to thank Mrs. Tania Rico, librarian at Elvas, for sending copies of the prophecy and the catalogue, which the authors would otherwise not have been able to access.

55. Cristóbal López de Cañete, Compendio de los pronosticos y baticinios antiguos y modernos que publican la declinación general de la secta de Mahoma, y libertad de Hierusalem y Palestina, Granada, Apud Francisco Heylan, 1630.

56. Ms. 354, Domingos Lavadinho, Manuscritos e outros documentos da biblioteca municipal de Elvas, vol. 2, Elvas, Tipografía Progresso, 1948, p. 42. We have not been able to consult this last prophecy and thus we do not know whether the two texts are the same.

57. More information on Friar Jean de Roquetaillade hand his prophecies can be found in G. Wiegers, "Jean de Roquetaillade's Prophecies."

58. Fray Benito was known for his piety and it is said that the image of Christ in Montserrat spoke to him in a vision. "Ut Anachoreticam vitam deligas" (Pedro Serra y Postius, Epitome historico del portentoso santuario y Real Monasterio de Nuestra Señora de Monserrate. Ilustrado con los sucessos historicos mas memorables de los principes, sus devotos y bienhechores. Dividese en quatro partes que consagra ... Barcelona por Pablo Campins ... se hallara en la Casa de la Procura de Monserrate ..., 1747, p. 466, http://bdh.bne.es/bnesearch/detalle/bdh0000081749). Serra y Postius' work was dedicated to the Portuguese King 1689-1750. See also, Ernest Zaragoza y Pascual, Els ermitans de Montserrat. Història d'una institució benedictina singular, Barcelona, Publicacions de l'Abadia de Montserrat, 1993, pp. 25-26; Fray Antonio de Yepes, Coronica general de la Orden de San Benito, Patriarca de Religiosos, Vol. 4, Valladolid, Francisco Fernández de Córdoba, 1613, p. 244v; and Gregorio de Argaíz, La Perla de Cataluña. Historia de Nuestra Señora de Monserrate, Madrid, Imprenta de Andrés García de la Iglesia, 1677, pp. 139-140.

59. According to one of the manuscripts of Serra y Postius' work currently preserved at the Universitat de Barcelona (Francisco Miquel Rosell, Inventario General de Manuscritos de la Biblioteca Universitaria de Barcelona, Volumen 1 (1-500), Madrid, Direcciones Generales de Enseñanza Universitaria y de Archivos y Bibliotecas, 1958, p. 238: Manuscripts 186-197: "Historia etc. principalmente en lo que pertenece a María Santísima dedicada, por Pedro Serra y Postius" and here "Recuerdo de Fr. Benito de Aragón," f. 76. We thank Mr. Joan Miquel Oliver from the Library of the University of Barcelona for sending us the copies of this text and also of the "Conquista de Granada" in the same volume (Manuscripts 186-197).

60. "Tambien cohpero muy mucho en el logro de esta victoria la virgen de Monserrate, cuya verdad se canoniza con ver que en ese propio año de 1492 subieron ennambos Reyes Don Fernando y Doña Isabel a la portentosa Montaña, y rindiendo gracias..." Conquista de Granada, ff. $143 \mathrm{r}-\mathrm{v}$.

61. BNP Cod. 798, f. 207r: "Depois de destruida e Seyta Mahometana em Espanha [...] se tratará nella, a recuperação da Terra Sancta."

62. Mònica Colominas Aparicio, "Profecía, conversión y polémica islamocristiana en la Iberia alto-moderna (siglo XV). Alfonso de Jaén y el círculo del obispo don Martín García," in Visiones imperiales y profecía. Roma, España, Nuevo Mundo, eds. Stefania Pastore, and Mercedes GarcíaArenal, Madrid, Abada Editores, 2018, pp. 51-77. Manuel Montoza Coca, "Los sermones de don Martín García, obispo de Barcelona. Edición y estudio," PhD Diss., 2 vols, Universitat de Barcelona, 2018, vol. 1 and 2.

63. BNP Cod. 798, ff. 286v-287r. Curiously, King Ferdinand is not mentioned in the edition of the work, cf. P. A. Vieira, De profecia ..., p. 25.

64. BNP Cod. 798, ff. 145v-146r: "que nunca o Reyno de Portugál se uniria ao de Castella"

65. Lisboa, Na Impressão Regia, 1809, pp. 33-37, https://hdl.handle.net/2027/wu.89081034100.

66. "nesta obra se nega avinda de El Rei D. Sebastião, e contém as profecias em que se fundão os apaixonados desta vinda, analizadas e desmentidas."

Hamsa, 6 | 2020 
67. See, Pieter Sjoerd van Koningsveld, and Gerard Wiegers, "The Parchment of the "Torre Turpiana'. The Original Document and its Early Interpreters," Al-Qanțara. Revista de Estudios Árabes 24, No. 2 (2003), pp. 327-358; idem, The Sacromonte Parchment and Lead Books. Critical Edition of the Arabic Texts and Analysis of the Religious Ideas. Presentation of a Dutch research project, Granada, 19 March 2019,19.00-21.00 hours. With images of the original Lead Books and the Parchment. s.1.: Avondrood, 2019.

68. See for a study of the topos in the literature, Soledad Carrasco Urgoiti, El moro de Granada en la literatura. Del siglo XV al XIX, Madrid, Revista de Occidente, 1956.

69. M. García-Arenal, “Granada as a New Jerusalem,” pp. 15-16.

70. See, for example, the recently discovered prophecy Tawq al-hamama discussed in Carmen Barceló and Ana Labarta, “Tawq al-hamama'. Un muwaššah apocalíptico," in Traducir el mundo árabe. Homenaje a Leonor Martínez Martín, eds. Mònica Rius et al., Barcelona, Universitat de Barcelona, 2014, pp. 93-131.

71. "Elhe" in the original.

72. "o quer" (or perhaps, "o quem") in the original.

73. "dão" in the original.

74. "perdeo" in the original.

\section{ABSTRACTS}

This paper argues that the hitherto unknown Portuguese "Profesias dadas por um Mouro de Granada" (Prophecies given by a Moor of Granada) (copied $18^{\text {th }}$ c.) should be seen as an example of messianic-political prophetic imagination in early modern Portugal and Spain. Our discussion will focus on the political uses of Sebastianism in Portugal and on the various ways in which prophetic language became entangled with broader prophetic discourses in the Iberian territories that resulted from centuries of Christian military and religious struggle with Islam and Muslims.

Este artigo argumenta que, o até agora desconhecido manuscrito português "Profesias dadas por um Mouro de Granada" (copiado no séc. XVIII), deve ser visto como um exemplo da imaginação profética messiânico-política no Portugal e na Espanha moderna. A nossa discussão focar-se-á nos usos políticos do Sebastianismo em Portugal e nas variadas formas pelas quais a linguagem profética se enreda nos discursos proféticos mais amplos nos territórios ibéricos, que resultam dos séculos das lutas militares e religiosas com o Islão e os Muçulmanos.

\section{INDEX}

Keywords: Iberian Prophecies, Portugal, Spain, Sebastianism, Islam and Muslims, Granada Palavras-chave: Profecias Ibéricas, Portugal, Espanha, Sebastianismo, islamismo e muçulmanos, Granada 


\section{AUTHORS}

\section{MÒNICA COLOMINAS APARICIO}

University of Amsterdam, Amsterdam School of Historical Studies (ASH)/ Max Planck Institute for the History of Science, Berlin

m.colominasaparicio[at]uva.nl

\section{GERARD WIEGERS}

University of Amsterdam, Amsterdam School of Historical Studies (ASH)

g.a.wiegers[at]uva.nl 